UDC 330.131.7:636.2.034 (477)

\title{
RISKS OF DAIRY FARMING IN UKRAINE AND WAYS OF THEIR MINIMIZATION AND NEUTRALIZATION
}

\author{
O. M. Varchenko ${ }^{1}$, V. I. Radko ${ }^{2}$, O. O. Rudych ${ }^{1}$, I. V. Svynous ${ }^{1}$, K. V. Tkachenko ${ }^{1}$ \\ ${ }^{1}$ Bila Tserkva National Agrarian University, \\ 8/1, Soborna Sq, Bila Tserkva, 09117, Ukraine \\ ${ }^{2}$ National University of Life and Environmental Sciences \\ 11, Heroiv Oborony Str, Kyiv, 03041, Ukraine
}

E-mail:omvarchenko@ukr.net,radko@ukr.net,8282@ukr.net, isvinous@ukr.net,k-tkachenko@ukr.net

Received January 19, 2019 / Received February 27, 2019 / Accepted March 22, 2019

\begin{abstract}
Aim. To identify the main types of risks, remarkable for agricultural dairy production, to evaluate the consequences of their increase and to substantiate a comprehensive system of managing them on the level of enterprise which would promote their minimization and neutralization. Methods. Common methods and techniques were applied in the study: a combination of scientific techniques of abstract-logical method of elaborating theoretical provisions, deduction method while isolating specific risks in dairy farming from the total amount, empirical methods of investigating the activity of dairy enterprises and computer generated simulation while substantiating practical instruments of risk management in agricultural dairy production. The correlation-regression analysis was used for statistical processing of the data and study results. Results. During the investigation the following kinds of risks in dairy production were isolated: natural, ecological, technological, market-related risks. The natural risk is related to the environmental impact, first and foremost, to the change in temperature regime of the environment of keeping cows, ecological component of manure utilization. The technological risk is characterized by violating the conditions of keeping cows at farms, which is manifested via loss and disposal of cows from the core herd. It has been found that currently the distribution of diseases, i.e. epizootic situation in the country, presents increased risk for farms. One of the ways to neutralize and minimize the manifestation of technological risks is improving biosafety of stock breeding complexes and developing the insurance of livestock. In addition to risks of diseases (infectious, invasion, non-contagious) and other standard risks (fire, natural disasters, etc.), it is reasonable to insure against the following kinds of risks: interrupted production (caused by death or loss of insured animals), after which current expenses for renewal of production or forfeited profit would be reimbursed automatically or after submission of confirmation documents; transportation of animals, including sea, air, and railway travel; expenses to remove the remains of animals after the insured event which caused their death; reimbursing the expenses for elimination of consequences, caused by infectious diseases, which made it impossible to renew the production without prior application of disinfectants. While evaluating market-related risks, special attention should be given to the relations of producers and processors of milk. Market risks are closely related to technological risks, as milk quality has a decisive impact on the formation of procurement prices. Conclusions. The systematization of risks in dairy farming should be performed in accordance to the total system of their manifestation and to specialized identification which characterizes specificities of this sphere. The probability of most risks, occurring in dairy production, is considerably dependent on the efficiency of managers of agricultural enterprises and partially on legislative and executive branches of power (in the part of legislative provisions). Currently the mitigation of environmental risks is possible only on condition of searching for internal reserves of ensuring the stability of dairy farming, which envisages creating conditions for production of high quality milk, minimization of expenses for its production and sale, compliance with agreements with contractors.
\end{abstract}

Keywords: dairy farming, industry risk, natural risk, technological risk, ecological risk, market-related risk.

DOI:

\section{INTRODUCTION}

The exacerbation of crisis in domestic dairy farming

(C) O. M. VARCHENKO, V. I. RADKO, O. O. RUDYCH, I. V. SVYNOUS, K. V. TKACHENKO, 2019 is explained by unfavorable impact of many external and internal factors, causing the disturbance in optimal use of resource potential of the enterprise while producing a required volume of milk for population and 
processing industry, which does not ensure a sufficient level of profitability and income to maintain extended reproduction and increase the competitiveness of products. These conditions increase the risks in the development of dairy enterprises which requires the introduction of a working system of risk management from economic subjects.

We believe that the main purpose of creating the system of risk management in agricultural milk-producing enterprises is enhancing the stability of activity via timely detection of the main factors of risks and threats, which lead to the aggravation of enterprise activity, using the elaboration and implementation of preventive measures on neutralization and minimization of the negative impact of the detected risks. It is evident that the issues of adapting to the risks of agricultural production, related to specificities of natural and socioeconomic conditions of economic activity, are of great relevance to maintaining stable functioning of dairy producers. Agriculture, dairy farming in particular, is one of the riskiest industries, notable for a long period of return of investment.

The urgency of studying the issues of identification and substantiation of the functional system of minimizing and neutralizing risks by economic subjects in dairy farming is confirmed by close attention of domestic scientists to determining threats and potential possibilities for sustainable development [1-3]. At the same time, while identifying and determining the risks in dairy farming, there is a need to expand the study spectrum based on the approaches to ensuring sustainable development on the one hand, and to substantiate the approaches to evaluating the risks of technical-technological matters, health and safety of animals, organization-management nature on the other hand, which would promote the formation of the comprehensive system of risk management on the level of agricultural enterprise and the elaboration of adaptation-related management decisions.

The review of foreign scientific literature demonstrated that the issues of investigating the manifestation of destructive phenomena in the development of dairy farming and elaboration of relevant instruments of combatting them are widely presentable and cover various matters, in particular, the development of dairy farming is under the impact of innovations, which caused enhanced concentration and specialization, and ensured the gain in productivity of cows and the possibility of using the mechanism of preserving resources on dairy farms, enhanced the profitability of this sphere (these tendencies are also notable for the development of Ukrainian dairy farming) [4].

It should be noted that the widest group is a group of industrial risks, mostly manifested by specific deviations from technological requirements of organizing milk production, untimeliness and poor substantiation of organization-management decisions. It was proven that investing capital into establishing modern innovational farms of intense type was accompanied by high risks which was confirmed by the results of studying the efficiency of different technologies of milk production in the aspect of the productivity of cows and profitability based on estimating standard deviation of the actual result from the average value, which is greatly provided by productive features of cows $[5,6]$. Thus, the innovational development in genetic and technological directions caused the enhanced productivity of cows and economic indices of development, but it also requires optimization of the impact of the industry on environment which requires the introduction of a comprehensive system of managing and processing manure and other components, causing ecological risks, at the level of farms.

It is obvious that depending on livestock numbers, type of reproduction, technologies of keeping cattle and other factors, it is especially relevant to study different specialization levels of commodity producers while elaborating strategies. It is known that one of functional instruments of risk management is diversification of industrial production, which is proven by the obtained results of investigations of French scientists, stating that small farms with mixed industrial program (dairy and beef production) are more stable in terms of anticipated incomes and profit variations compared to specialized farms [7]. Both domestic and international communities pay great attention to the issues of minimizing risks, related to compliance with the requirements to organizing the reproduction of dairy livestock. One of the directions is reducing the reproduction cycle duration; optimizing the dairy herd structure; reducing the number of open cows to increase the intensity of selecting heifers for replacement and extensive reproduction of productive livestock; intensifying the breeding replacement (breeding) heifers; minimizing the expenses to farm dairy cows; sufficient financial provision for reproduction process as well as introduction of automated systems of stock management for monitoring of reproductive indices $[8,9]$.

Therefore, highlighted tendencies in the development of dairy farming in agricultural enterprises both in domestic and foreign practice condition the increase 
in industrial, market-related and other kinds of risks, but at present global climatic changes cause the manifestation of ecological risks, diverse studies of which in foreign scientific literature provided for the formation of both methodological and practical approaches to their neutralization, in particular, the methodological approach to evaluating ecological efficiency of different systems of milk production on the basis of consideration of the intensity of greenhouse gas emissions [10]; the study of the impact on intensification of fodder production, their preparation and ratios of cows as well as technologies of keeping manure on the environment, and substantiation of instruments in terms of their neutralization and mitigation of negative consequences [11].

The implementation of events related to the readiness of agricultural producers to accept and understand the risks, related to climate change, and thus to the elaboration of measures to overcome them, is of great importance both on the national and economic levels to substantiate the strategies of adapting dairy farming. In this aspect, there is an interesting assumption that understanding and thus application of measures on flexible adaptation of farmers to climate change is related to livestock numbers of the farm, as large and medium enterprises took relevant management decisions in this area, but almost all farmers believed that climate change would have the highest impact on the productivity of cattle and fodder production [12].

Therefore, the development of the methodological instruments in identifying and evaluating the risks of dairy farming of different origin as well as the elaboration of instruments of minimizing and neutralizing them in short- and long-term perspective for agricultural farms are especially relevant as, on the one hand, it will promote ensuring scientific support for commodity producers in the understanding of this phenomenon, the origin and elaboration of practical actions. It is evident that risks in dairy farming are dynamic, as an insignificant change in external and internal factors of functioning of agricultural enterprises affect the occurrence, impact the force and risk vector which requires systematic monitoring on the level of the country and the application of risk management instruments by producers directly.

Risk is an extremely complicated, multifaceted and multi-aspect phenomenon in economics and any other sphere. Economic risk is an economic category, reflecting the possibility and degree of deviation from the aim (both towards the positive and negative) in the course of implementing economic activity of the enterprise.

In scientific literature, risk is usually defined as "suffering a loss or damage", "probability of failure or loss, related to a specific direction of actions", "danger, threat", "profit, viewed as some benefit for profitable acceptance of risk", "uncertainty of future flows". The table below presents the approaches to defining the "risk" category by some economists.

It should be noted that risks, affecting the activity of an economic subject, are defined in economic literature as "economic", "entrepreneurial", "industrial", "commercial" i.e. the terms "economic risk", "industrial risk", "entrepreneurial risk", "risk of commercial activity" are most frequently used in one context. We share the opinion of the need to systematize kinds of risks, determine directions of their effect and nature of origin, which would promote improving entrepreneurial culture of agricultural producers, their awareness and willingness to take urgent management decisions within the risk management system [13].

Noteworthy is the fact that at present domestic dairy enterprises do not apply methods of detecting, preventing and minimizing risks in their daily economic activity. At the same time, foreign companies study models of management in scientific literature and use them successfully, reducing the probability of unscheduled losses and expenses.

Ukrainian scientists believe that the sequence of actualizing the risk and uncertainty consists of the following elements: reasons; phenomena (events); effect on an object; change in the state of object $[14,15]$. Thus, according to this approach the primary source of risk occurrence is a "reason" i.e. external economic conditions (external factors) which affect the manifestation of "a phenomenon or event", i.e. economic situation in this enterprise. The "effect on the object" i.e. actions, management decisions, taken by enterprise management, are the following stage. The final stage reveals the consequences of taken decisions, i.e. change in the state of the object.

The most comprehensive system of risk classification was suggested by Blank, a Ukrainian scientist. It may be adjusted to the investigation of economic risks as this classification includes most financial and investment risks. However, taking into consideration the manifestation of specific factors in the activity of farms, which should impact the formation of risks, it is reasonable to pay more attention to these factors. This 
approach will consider risk factors, which are the basis of forming the elements of economic risk and, as a result, its primary reason, which is confirmed by foreign scientists [16].

Some Ukrainian scientists studied identification and classification of risks, based on the simulation of business projects [17]. Grouping economic risks may involve the following classification features: depending on the source of origin - financial, technical-technological, legal risks; depending on the nature of origin - state, management, market, contact basis (origin).

Foreign scientists isolate two following groups of risks most frequently: systematic risk, formed by external environment factors, which is not subject to targeted impact of the enterprise and requires flexible adjustment to its consequences; non-systematic risk, the source of origin of which is in factors of internal environment of the enterprise, i.e. there is impact on specific elements, branches of the enterprises without impeding the integrity of its functioning [18]. At the same time, there is an approach, which divides all the risks into two groups: objective risks, i.e. risks, which may be impacted by managers, and subjective risks which are not subject to any management [19]. In their turn, each group is divided into exogenous risks, i.e. the risks, which are formed on the level of the enterprise and dependent on the taken management decisions; endogenous risks, which do not depend on the enterprise itself [20]. This classification is similar to the previous one, as it considers the risk by one classification feature only which prevents from obtaining an integral picture of forming the risk for the enterprise. However, this approach traces a relevant element of the risk - the possibility of managing it.

\section{MATERIALS AND METHODS}

The aim of the study was to obtain information about the sources of risks in dairy farming, which are determined by the managers of agricultural enterprises and leading specialists as well as the direction of their impact on the deviation of resulting indices. The information, used in the study, was collected via the survey among commodity producers from 824 randomly selected farms. The survey was conducted in 2017-2018 and lasted for 9 months. The survey had 75 questions, characterizing the potential of dairy farming, indices of productivity, technologies, financial-economic and other factors. In addition, the survey had a possible list of risk management instruments to identify the awareness of farmers, their relevance and practical application. The farmers evaluated the sources by the probability of their occurrence and impact on economic activity results by Likert scale of five points - from 1 (insignificant) to 5 (very relevant) which allowed isolating and conducting comprehensive study in terms of most common kinds of risks.

The obtained information was used as a basis for analytical investigation on the following issues: adaptation of milk producers to climate changes, creating the relevant microclimate of keeping cows; identification of risks, caused by economic relations of milk producers and processing enterprises; study of the practice of using instruments of risk management by agricultural milk producers.

The study also involved the available statistical foundation of dairy farming at the level of the State Statistics Service of Ukraine and the Ministry of Agrarian Policy of Ukraine.

The indices of mathematical statistics - the variation coefficient and mean square deviations of resulting indices are the methodological foundation of evaluating risks of agricultural enterprises in dairy farming. In addition, our investigation of pricing risks involved the use of correlation-regression models of milk profitability dependence on equal share of milk price and cost of material and technical resources, feeds and the dependence of the price of milk supplies by agricultural enterprises to processing enterprises on the volumes of milk supplies, mass share of fat and protein.

\section{RESULTS AND DISCUSSION}

While studying the risks in dairy farming, we used the approach of their classification on the level of the environment, their manifestation and the possibility of managing them. The risks of dairy farming are complicated. The sources of their manifestation are of different nature, and the consequences are remarkable for a wide variety of manifestations. It should be noted that the first and foremost specificity of entrepreneurial activity in milk production is high susceptibility of dairy cows to the impact of objective risk factors, namely, diseases, weather conditions, affecting the fodder resources, limited terms of storing raw milk materials compared to other kinds of agricultural products, etc.

During the investigation based on summary of information from agricultural enterprises and private farms - milk producers, we conducted the survey and isolated the following kinds of risks for dairy farming: natural risks - change in natural-climatic conditions, which leads to losses due to the reduced productivity of animals, and in some cases - to their death and addi- 


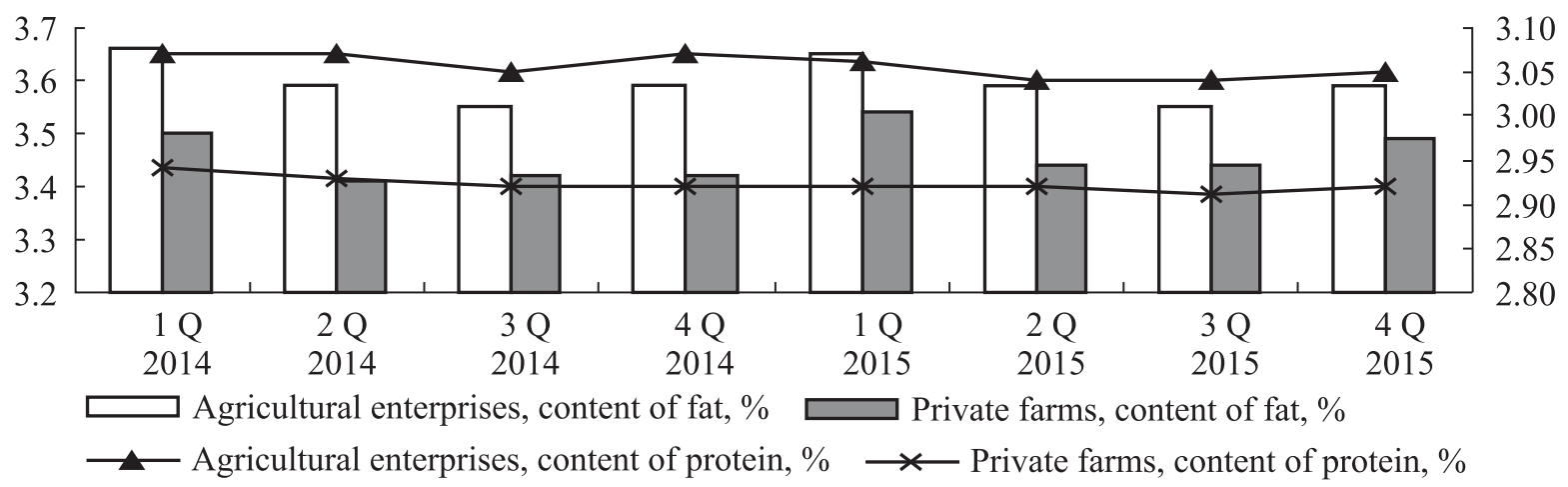

Fig. 1. Dynamics of fluctuations in the content of fat and protein in milk, sold by corporate sector farms to processing enterprises, \%. Source: composed and estimated according to the data of the State Statistics Service of Ukraine

tional losses due to the change in technologies of keeping cows; ecological risks - additional expenses for the disposal of manure and other kinds of by-products and associated products of dairy farming; limitations in the level of concentration of livestock in some regions of Ukraine; technological risks - losses, related to disposal and death of cows due to the failure to comply with the conditions of the technology of keeping animals, a high level of disposing of livestock with the purpose of using intense technologies; market-related risks losses due to fluctuation of prices for initial material resources and milk and the supply and demand; regulatory risks - losses due to adopted legislative acts.

Thus, the most considerable risk in dairy farming is natural risk, related to the impact of environment, change in temperature regime of the environment of keeping cows. According to the data of the US Department of Agriculture, the losses due to overwarming of animals in dairy farming are evaluated in the range from USD 800 million to 1.5 billion a year. The environment temperature of over $+20{ }^{\circ} \mathrm{C}$ causes discomfort for dairy cows, which is accompanied with stress, and reduced consumption of fodder, slows down the fermentation processes in the rumen and a considerable decrease in milk yield.

The results of studies demonstrate that heat stress triggers significant financial losses. As per estimates, on average $80 \%$ of losses are suffered due to the reduced dairy productivity, and $20 \%$ are related to the health of animals, to reproduction and immunity mostly. The first consequence of overwarming is the reduction in yields by $10-35 \%$. There is an increasing risk of acidosis [21-23].

In addition, heat stress of cows is accompanied with the increase in rectal temperature, accelerated breathing, and loss of appetite. The content of non-fat dry substances, protein, lactose and fat decreases in milk. It should be noted that temperature fluctuations have less impact on the content of lactose and mineral substances than on protein and fat.

In the regions with a wide range of temperature fluctuations, which include Ukraine, the content of fat in milk may be $0.4 \%$ and protein $-0.2 \%$ less in summer period compared to winter. This conclusion is confirmed by the data of the State Statistics Service of Ukraine (Fig. 1).

The data in Fig. 1 demonstrate that in 2014-2015 the lowest content of fat was in milk, obtained from agricultural enterprises - III quarter, private farms - II-III quarter, protein - in corporate sector farms of agrarian economics and private farms - III quarter, respectively. It is obvious that to avoid economic losses due to the manifestation of temperature fluctuations, it is important to create comfortable conditions of keeping animals. In addition to external cooling, it is important to feed animals with correct and balanced fodder in the hot season to decrease the negative impact of heat stress. The ratio should be energy-wise richer than usually in order to prevent negative energy balance [24]. Due to the reduced consumption of fodder in the period of high mean daily temperatures, the fodder should contain more crude protein, but its amount should not exceed the norm. The process of digesting excessive protein accumulates heat and requires additional energy which could be used for milk production.

It is noteworthy to concentrate attention on several management technologies of creating comfort for animals in hot weather: the diet should be balanced, and fodder should be accessible for animals, thus, enough space for animals should be ensured near the feed table; the feed table should be regularly cleaned; the diet should be regularly analyzed to comply therewith; only high quality fodder should be sold; sharp changes in the diet should be minimized to prevent loss of appe- 
tite; mixed diet should be used for animals to consume balanced fodder in a stable manner with minimal sorting. To minimize heat formation, a larger part of fodder should be fed in cooler hours (for instance, between four and six in the morning, and between nine and eleven at night).

Climatic changes, remarkable for Ukraine now, in particular, decrease in precipitation, lead to reduced duration of the grazing period in the Forest-Steppe from 6 down to 3 months. For instance, 20 years ago in summer, the daily duration of the grazing period was about 8-9 h, and now $-3-4 \mathrm{~h}$ which leads to the increase in the production costs of the milk, obtained from private farms.

The development of dairy farming on the industrial basis requires the formation of intense fodder resources, rational concentration of livestock on the limited territory, change in traditional forms of their keeping, which conditions the need of using a great amount of water from natural and artificial water bodies and it has a negative impact on their ecological condition and environment. It is believed that intense type of developing dairy farming is one of the highest water consumers among agriculture industries.

It should be noted that high concentration of livestock on limited areas, the application of hydraulic systems of collecting and removing excrements of animals lead to the formation of very high volumes of liquid manure and large amounts of harmful volatile chemical substances, related to the use of industrial premises, to unpleasant smells, intense noise, etc.

While solving the issues of locating livestock breeding complexes, selecting the systems of processing and

Table 1. The dynamics of emissions of enteric (digestive) fermentation into environment by cows, kept by agricultural enterprises. Source: composed and estimated according to the data of the State Statistics Service of Ukraine

\begin{tabular}{|c|c|c|c|c|}
\hline \multirow[b]{2}{*}{ Year } & \multirow{2}{*}{$\begin{array}{c}\text { Number } \\
\text { of enter- } \\
\text { prises }\end{array}$} & \multicolumn{2}{|c|}{ Emission volumes } & \multirow{2}{*}{$\begin{array}{c}\text { Average } \\
\text { emission } \\
\text { from one } \\
\text { enterprise, } \\
\mathrm{t}\end{array}$} \\
\hline & & $\mathrm{t}$ & $\begin{array}{l}\text { in } \% \\
\text { of the } \\
\text { total }\end{array}$ & \\
\hline 2011 & 331 & 9466.3 & 0.2 & 28.6 \\
\hline 2012 & 332 & 10010.3 & 0.2 & 30.2 \\
\hline 2013 & 332 & 9864.1 & 0.2 & 29.7 \\
\hline 2014 & 329 & 9841.6 & 0.3 & 29.9 \\
\hline 2015 & 318 & 10351.6 & 0.4 & 32.5 \\
\hline $\begin{array}{c}2015 \\
\text { to } 2011 \text {, in \% }\end{array}$ & 96.1 & 109.4 & 0.2 t.p. & 113.6 \\
\hline
\end{tabular}

using the dairy farming waste, the specialists believe that relevant environmental components - atmospheric air, soil, water bodies - are practically inexhaustible from the ecological standpoint. However, the experience of using industrial premises demonstrates intense pollution of environmental objects and unfavorable impact on living conditions of rural population. Due to this fact, the protection of environment from pollution, prevention of infectious, invasive and other diseases of humans and animals are related to the actions of creating efficient systems of collection, removal, storage, disinfection and application of manure and gutter drains, improvement and efficient work of air purifiers, scientifically grounded location of stock breeding complexes and premises for manure accumulation with the consideration of human settlements, sources of drinking water supplies and other objects, i.e. with the complex of hygienic, technological, agricultural and architecture-building measures.

In terms of waste production, one dairy cow is equivalent to 16 human equivalents, and young cattle - to 12 . The process of producing $1 \mathrm{~kg}$ of milk also results in $25 \mathrm{~kg}$ of wastes and $13 \mathrm{~kg}$ of wastewater. The utilization of such a great amount of wastes requires considerable expenses. The cost of waste treatment facilities for storage and processing of wastes approximates one third of the total cost of the livestock breeding complex [25].

It was also determined by us that the industrial risk in dairy farming development at agricultural enterprises is conditioned by the emission of enteric (digestive) fermentation into environment. According to the data of the State Statistics Service of Ukraine, during the investigated period there was an increase in enteric (digestive) fermentation by $9.4 \%$ in total and by $13.6 \%$ as calculated per one corporate sector farm of agrarian economy (Table 1).

One of the main measures of reducing technogenic burden on environment is installing air purifiers in enterprises. However, the results of our studies demonstrated that 87 agricultural enterprises in Kyiv, Vinnytsia and Ternopil regions out of 93 investigated ones do not allocate any finances for procurement of air purifiers, which is $94 \%$ from the total amount.

The increased risks in dairy farming are observed for manure disposal too. This is demonstrated by statistical data regarding the increased volumes of wastes by $13.8 \%$ in the process of cleaning, storing and using manure in dairy farming as per one agricultural enterprise (Table 2). This tendency may be explained by the 
increase in the concentration of cows at corporate sector farms of agrarian economy.

The results of our studies demonstrated that most investigated agricultural enterprises-producers of dairy production (56 investigated farms) use manure storages of pond type and of open type to accumulate manure which increases the process of emissions of harmful products of anaerobic fermentation into environment. It demonstrates that the management of investigated agricultural milk-producing enterprises does not pay enough attention to nature protection.

At present, most agricultural enterprises do not invest additional finances into disposal of by-products (manure) of dairy farming, the investigated enterprises do not invest into nature protection. This situation creates increased risks of negative impact of dairy farming industry on the stability of developing enterprises. To turn the attention of owners and managers of agricultural milk-producing enterprises to these important issues and to promote their investments into practical events of minimizing negative impact of production on the environment, we deem it necessary to separate a section "Requirements to environment pollution" in the suggested regulation "Production of raw milk and management of quality and safety", which should specify that the producer should comply with current regulatory acts on environment protection while producing milk.

Noteworthy is technological risk, characterized by violations of conditions of keeping cows at farms, which is manifested via loss and disposal of cows from the core herd. The comprehensive analysis of farm activity demonstrated that the rate of loss of heifers is $3-6 \%$ from the total number of newborns. The main reason of death is the disease of digestive and breathing organs, as this share covers $77 \%$ of all the pathologies. First and foremost, these diseases are caused by the disrupted technology of feeding newborn calves (absence of the first portion of colostral milk during the first hour of life, frequency of daily feeding and amount of non-skimmed milk (under 500 1), feeding with substitutes of non-skimmed milk (SNM) in early life (15-20 days) and low quality of SNM, noncompliance with veterinary-sanitary norms; violated norms of keeping young cattle - microclimate in cattle breeding premises does not correspond to zoohygienic norms (humidity, droughts, low temperature), non-balanced diets for cows in terms of the main components which leads to impaired metabolism in the organism of the mother and newborn calves, due to which they are more susceptible to different diseases; feeding pregnant cows in the last months of dry period with silos of poor quality or hay, which has a negative impact on the health of progeny [26].

We found out that divisions for dry cows are absent at almost all the farms. At many farms, maternity barns, prophylactoria, and fly camps do not correspond to zoohygienic requirements. During calving time, the maternity barns are overloaded, the principle "everything is busy - everything is free" is not followed. It is obvious that the violation of technological requirements increases industrial risks for commodity producers and requires substantiation of measures to avoid and minimize negative impact.

It was established that during the investigated period the loss of cattle in agricultural enterprises and private farms, producing milk, fluctuated in the range of up to $1 \%$ in two recent years (Fig. 2).

Ukraine does not have state-approved indices of admissible loss of livestock and poultry. Some agricultural enterprises still solve the problem of normative technological losses using industry standards of Soviet times. However, they can develop such norms on their own.

It has been found that currently the distribution of diseases, i.e. epizootic situation in the country, presents increased risk for farms. As of April 01, 2017, there were no TB-free settlements in Ukraine. 3.4 million allergy studies on TB were conducted in 2016. As of March 01, 2017, Ukraine had 9 places with leukosis 8 in Kharkiv and 1 in Rivne regions, where 1,414 sick animals were kept. Over 2.9 million serological inves-

Table 2. Dynamics of cleaning, storing and using manure as well as organic compounds of cows, kept at farms. Source: composed and estimated according to the data of the State Statistics Service of Ukraine

\begin{tabular}{|c|c|c|c|c|}
\hline \multirow[b]{2}{*}{ Year } & \multirow{2}{*}{$\begin{array}{c}\text { Number } \\
\text { of enter- } \\
\text { prises }\end{array}$} & \multicolumn{2}{|c|}{ Emission volumes } & \multirow{2}{*}{$\begin{array}{c}\text { Average } \\
\text { emission } \\
\text { from one } \\
\text { enterprise, } \\
\text { t }\end{array}$} \\
\hline & & $\mathrm{t}$ & $\begin{array}{l}\text { in } \% \\
\text { of the } \\
\text { total }\end{array}$ & \\
\hline 2011 & 352 & 5623.5 & 0.1 & 16.0 \\
\hline 2012 & 339 & 5534.7 & 0.1 & 16.3 \\
\hline 2013 & 329 & 5622.3 & 0.1 & 17.1 \\
\hline 2014 & 310 & 5527.4 & 0.2 & 17.8 \\
\hline 2015 & 305 & 5536.1 & 0.2 & 18.2 \\
\hline $\begin{array}{c}2015 \\
\text { to } 2011 \text {, in } \%\end{array}$ & 86.6 & 98.4 & 0.2 t.p. & 113.8 \\
\hline
\end{tabular}




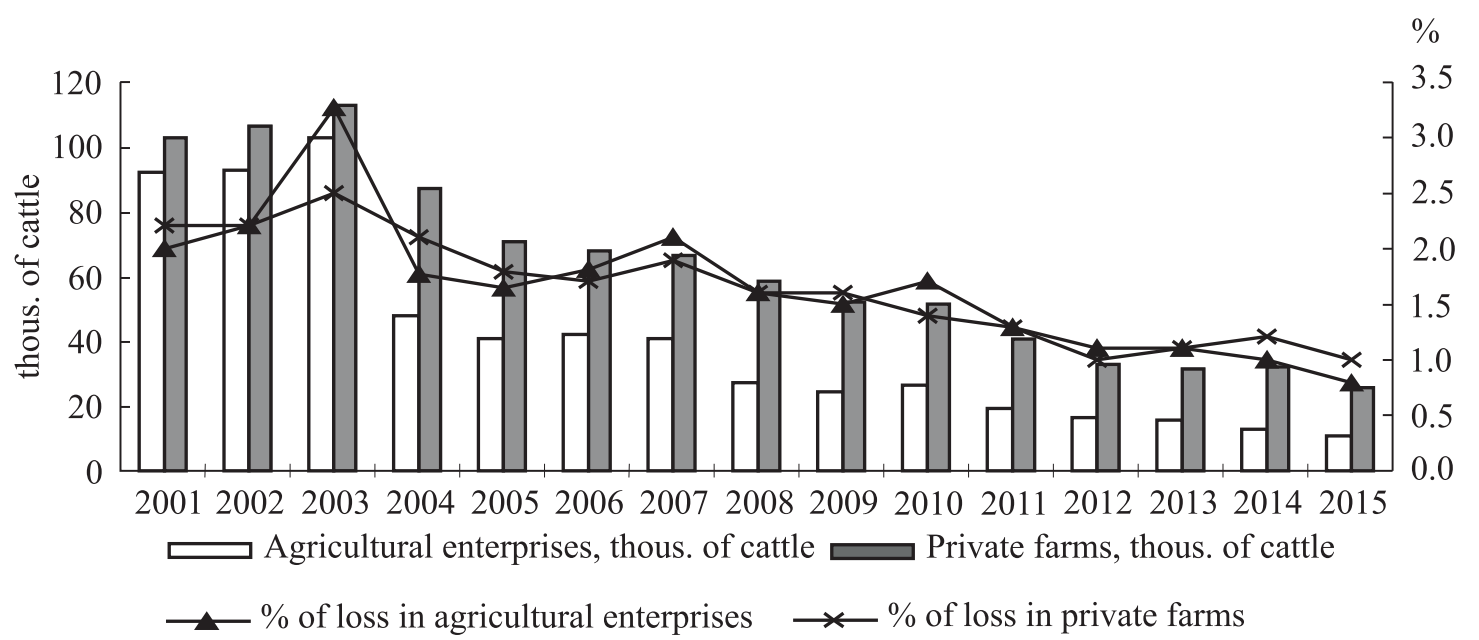

Fig. 2. Dynamics and percentage of cattle loss in agricultural enterprises and private farms. Source: composed and estimated according to the data of the State Statistics Service of Ukraine

tigations of cattle regarding leukosis were conducted during the previous year.

Taking into consideration the epidemiological situation outside of Ukraine and absence of vaccination, there is a risk of epidemic of dermatitis nodularis of cattle in the territory of our country. There is no specific treatment for this disease, and it inflicts animals of any age. The productivity of cows has decreased multifold, bulls may become temporarily or permanently sterile, infected pregnant cows have abortions or calves, infected with dermatitis nodularis.

The Office International des Epizootics (OIE) warns that the epidemic of bovine dermatitis nodularis has covered the following countries: Austria, Bulgaria, Armenia, Iran, Kazakhstan, Russia, Hungary. The outbreak of the viral disease took place $200 \mathrm{~km}$ from the border with Luhansk region, or $340 \mathrm{~km}$ from Kharkiv. Taking into consideration the fact that the disease attack rate is $100 \mathrm{~km}$ per day, the virus may enter Ukraine. According to the experts, if the virus spreads in the territory of Ukraine, the estimated loss of industrial herd in farms will be as follows: loss $-40-70 \%$, intravitam decrease in productivity $-30-40 \%$, loss of calves - up to $90 \%$, complete disposal of milk for quarantine period - 28 days [27]. To prevent spreading this disease, there should be a developed program of both vaccination and obligatory identification and registration of animals. The expenses for mere situation monitoring may amount to USD 350 million.

The aggravation of epizootic situation in Ukraine and the increased susceptibility of highly productive dairy cows to diseases causes higher expenses for zooveterinary events. The expenses, related to the procure- ment of biopreparations and disinfectants, used in dairy farming, are reflected in the column "the rest of material expenses".

Current expenses for protection of animals in agricultural enterprises - dairy farming producers are gradually increasing. This circumstance is triggered by the increased cost of biopreparations and disinfectants and the increased need of improving biosafety events of animal breeding complexes.

It is important to analyze the rates of expenses of agricultural enterprises for animal protection (Fig. 3).

The data in Fig. 3 demonstrate that during the analysis of agricultural enterprises there was a rapid increase in rates of expenses for animal protection means and their share in total expenses, which exceeded $10 \%$ in 2010-2015. This tendency may demonstrate the orientation of agricultural commodity producers towards intense milk production and the animal protection means and disinfectants ensure the production of high quality milk.

One of the ways to neutralize and minimize the manifestation of technological risks is improving biosafety of stock breeding complexes and developing the insurance of livestock. The insurance of animals as a type of property insurance envisages providing owners with insurance coverage for loss, death or undesired slaughter of animals. Regardless of this classification, this type of insurance envisages the implementation of some specific requirements while concluding the agreement - compliance with the conditions of keeping cattle and sanitary norms, vaccination, obligatory veterinary support to take an objective decision about the reasonability of further farming of animals, and if 


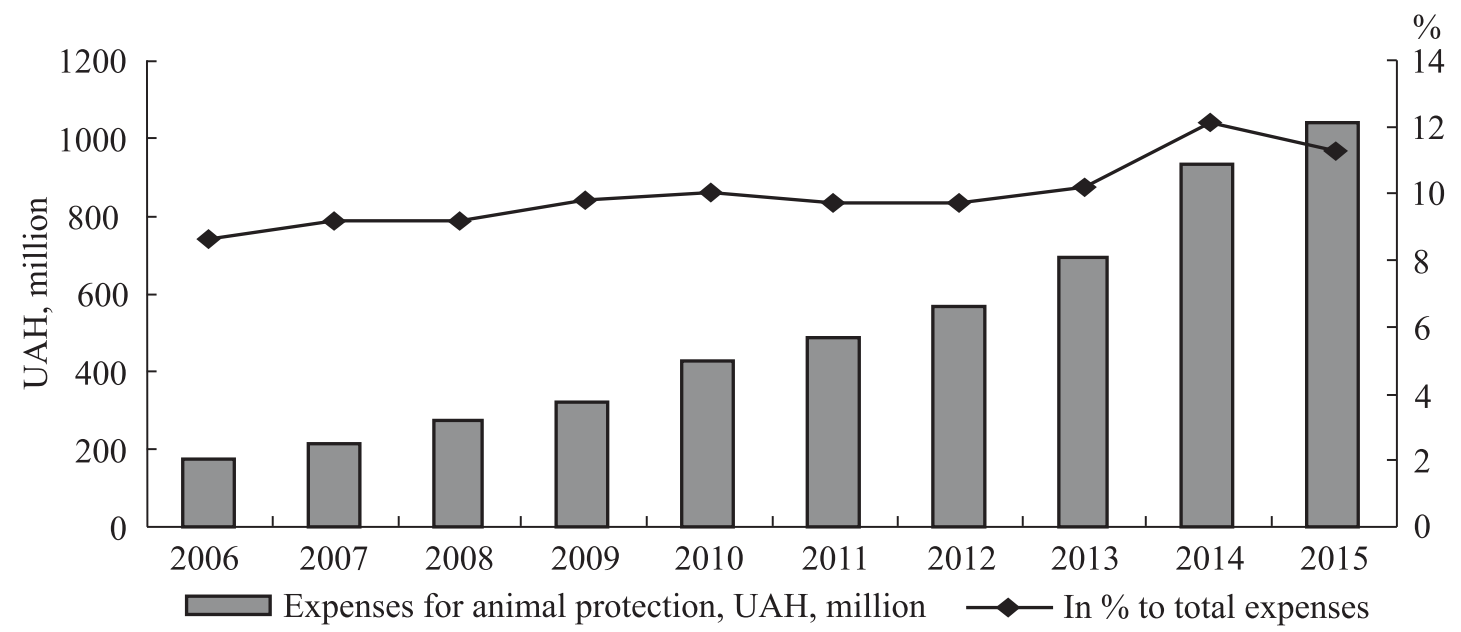

Fig. 3. Dynamics of expenses for animal protection means in agricultural enterprises of dairy farming. Source: composed and estimated according to the data of the State Statistics Service of Ukraine

an animal dies - provision of postmortem analysis of the remains.

The presence of the developed system of insurance for animal farming allows accelerating the obtaining of information about the disease or death of animals, determining the source of infection, and thus reduction of direct losses for a specific producer in the region and in the country in general. Insurance for animal farming is a way of ensuring safety of Ukrainian citizens and reducing the state expenses in case of massive outbreaks of epizootic diseases.

However, the process of introducing this insurance segment in our country takes place with the underestimation of its relevance to ensure human safety. At present, obligatory insurance has not covered even agricultural producers, whose animal products are sold to the population.

At present, as per the evaluation of the League of insurance organizations of Ukraine, the amount of annual premium for insurance of animals in Ukraine does not exceed UAH 100-150 thousand, and the reimbursement is given in the amount of $70 \%$ from the insured amount. The problem lies in the fact that the system of personification of animals is not efficient in our country. In addition, attention should be paid to poor quality of services from insurance companies [28]. In our opinion, the acceleration of this process could be promoted by the introduction of different forms of insurance, which would envisage both complete and partial coverage of losses that would allow the insurer to regulate the rate of expenses for the procurement of the certificate of insurance independently. To limit the losses of insurance companies in this market segment, it is important to have strict regulations for the technology of manufacturing animal products (the availability of a veterinary certificate for agricultural producers, intending to sell their products).

However, global experience demonstrates that the problems with insuring animals are not remarkable only for Ukraine. According to the statistics, specific insurance products for animal breeding are most common in Spain and Sweden where the coverage of farmers with insurance programs is up to $80 \%$ whereas in Germany this index does not exceed $30 \%$ [29].

In most developed countries the government is responsible for controlling the epidemiological situation in the country and provides compensations to farmers in case of loss or forced disposal of cattle, but is not responsible for loss, related to breaks in production. In some countries (Australia, Canada, the USA) the insurance of animals is provided by private insurance companies. However, insurance of animals on the basis of farmers' mutual insurance associations has been greatly spreading further. It involves insuring losses, caused by breaks in production due to such diseases as foot-andmouth disease or plague and due to milk contamination because of breaks in the system of ventilation and cooling. At present, some countries consider the possibility of introducing parametric insurance of animals.

Taking into consideration the aggravated epizootic situation in most countries, a regional index of losses is suggested to determine insurance rates. Its maximal value should not exceed the epizootic threshold (which is over $5 \%$ for bovine cattle in Ukraine).

In addition to risks of diseases (infectious, invasion, non-contagious) and other standard risks (fire, natural 
disasters, etc.), we consider it reasonable to provide insurance coverage for the following kinds of risks: interrupted production (caused by death or loss of insured animals), after which current expenses for renewal of production or forfeited profit would be reimbursed automatically or after submission of confirmation documents; transportation of animals, including sea, air, and railway travel; expenses for removing the remains of animals after the insured event which caused their death; reimbursing the expenses for elimination of consequences, caused by infectious diseases, which made it impossible to renew the production without prior application of disinfectants.

The insured amount may be established for each animal on condition that it has been individually accepted for insurance; for groups of animals, with the indication of the insured amount per an average statistical animal of each group. Individual insurance of animals is economically reasonable for the agricultural enterprise as in case of group insurance, the loss of 1-2 animals does not exceed the franchise level, i.e. the reimbursement of losses is done at the owner's expense. Due to this reason most insurance companies do not conclude agreements for individual insurance of animals. While determining the damage and compensation payments (contrary to insuring harvest), the value of the deductible franchise may be undetermined. In case of franchise, the decreasing coefficient is used to calculate the insurance premium from 0.5 to 10.0 depending on the regional index of the loss.

In recent years, the main reasons of the increase in costs of production for milk is the increase in the material costs and expenses for sales due to more expensive fodder, energy and other kinds of resources, which is the manifestation of market risks. A relevant factor is also a low level of productivity of cows and the quality of milk which also affects the cost of production of milk resources and further price formation for milk and milk products.

Correlation-regression equations of dependences were built to determine the impact of productivity factors for cows and equal share on milk profitability. Relative indices, specified in Table 3, are used to compare the indices in calculations.

The estimate results, presented in Table 3, demonstrate that the mentioned indices do not impact the negative tendency towards decreasing cow population. This fact may be the result of the disparity of prices, which took place in 1991-2000. During the investigated period, there was a process of eliminating the disparity of prices with a high level of the productivity of cows which would finally ensure positive value of the profitability level.

We calculated the determination coefficients by equal share indices to cumulative expenses, material-techni-

Table 3. Dynamics of cow population, productivity of cows, profitability of production and sale of milk at agricultural enterprises and equal shares. Source: composed and estimated according to the data of the State Statistics Service of Ukraine

\begin{tabular}{c|c|c|c|c|c|c}
\hline Year & $\begin{array}{c}\text { Cow } \\
\text { population, } \\
\text { mill. of cattle }\end{array}$ & $\begin{array}{c}\text { Profitability } \\
\text { of milk, \% }\end{array}$ & $\begin{array}{c}\text { Productivity, } \\
\mathrm{kg}\end{array}$ & $\begin{array}{c}\text { Index of equal } \\
\text { share to cumulative } \\
\text { expenses }\end{array}$ & $\begin{array}{c}\text { Index of equal } \\
\text { share to material- } \\
\text { technical resources }\end{array}$ & $\begin{array}{c}\text { Index of equal } \\
\text { share to costs } \\
\text { of fodder }\end{array}$ \\
\hline 2000 & 1851.0 & -6.0 & 1482 & 112.40 & 107.90 & 112.90 \\
2001 & 1675.2 & -0.8 & 1965 & 100.36 & 106.08 & 111.70 \\
2002 & 1401.8 & -13.8 & 2070 & 87.32 & 93.62 & 91.14 \\
2003 & 1100.0 & 9.9 & 1912 & 114.46 & 118.27 & 102.40 \\
2004 & 949.9 & -0.4 & 2303 & 99.42 & 101.19 & 132.15 \\
2005 & 866.2 & 12.2 & 2719 & 111.08 & 117.09 & 123.21 \\
2006 & 764.0 & -3.7 & 2833 & 75.88 & 82.81 & 82.52 \\
2007 & 678.6 & 13.8 & 2851 & 124.38 & 85.37 & 109.10 \\
2008 & 624.3 & 4.1 & 3080 & 85.93 & 90.59 & 85.58 \\
2009 & 604.6 & 1.4 & 3582 & 86.40 & 134.63 & 143.58 \\
2010 & 589.1 & 17.9 & 3666 & 133.02 & 87.18 & 95.74 \\
2011 & 583.7 & 18.5 & 3812 & 88.38 & 125.30 & 72.61 \\
2012 & 565.4 & 1.8 & 4343 & 81.18 & 88.75 & 81.42 \\
2013 & 560.3 & 13.1 & 4490 & 123.76 & 82.97 & 80.91 \\
2014 & 529.2 & 11.1 & 4683 & 90.33 & & \\
2015 & 505.1 & 12.7 & 5044 & 80.05 & & \\
\hline
\end{tabular}


cal resources, cost of fodder which allowed for the following conclusions:

- the dependence of milk profitability on productivity and equal share to cumulative expenses: by $40.7 \%$ from the first factor and $24.1 \%$ - from the second one. The cumulative impact of both factors equaled $64.8 \%$;

- the dependence of milk profitability on productivity and equal share to material-technical resources: by $42 \%$ from the first factor and $22.1 \%$ - from the second one. The cumulative impact of both factors equaled $64.1 \%$;

- the dependence of milk profitability on productivity and equal share to the cost of fodder: by $41.7 \%$ from the first factor and $13.1 \%$ - from the second one. The cumulative impact of both factors equaled $54.8 \%$.

The correlation-regression models of milk profitability dependence on the mentioned factors are as follows:

1) $Y=-41.9926+0.0054 X_{1}+0.2953 X_{2}$

2) $Y=-42.8717+0.0055 X_{1}+0.2919 X_{2}$

3)

$$
Y=-33.9995+0.0055 X_{1}+0.2058 X_{2}
$$

According to the estimated values of coefficients, the regression equation defines the increasing coefficient of variable $Y$ when $X_{i}$ is increased by one regarding the average value. The following conclusions can be made: the increase in the productivity of cows by $1 \mathrm{~kg}$ increases milk profitability by $0.005 \%$ regarding the average values; the increase in equal share indices to cumulative expenses, to material-technical expenses and costs of fodder by $1 \%$ increases milk profitability by $0.3 ; 0.29$ and $0.21 \%$ respectively.

The determined dependence of milk price on the season factor demonstrates low dependence of procurement prices on quality parameters of milk (content of fat and protein) with the prevailing dependence on the volumes of its supply. It is obvious that considerable fluctuations in prices in the course of a year have a negative impact on the income of agricultural producers. In 2009-2010 the amplitude of fluctuations in average prices for milk (the difference between prices in peak periods) was $60-70 \%$ and in $2008-25 \%$. In 2014-2015 this index was somewhat higher - up to $30-31 \%$ in hryvnia, or $19.5 \%$ when calculated in euro. At private farms, the season coefficient for the investigated period was even higher - 33-34 \% in hryvnia equivalent, or $21.6 \%$ in euro. It is noteworthy that this discrepancy does not exceed $15 \%$ in economically developed countries. Global experience demonstrates that if this line is crossed, the state makes intervention purchases of milk products (cheese, dry milk, butter) [19]. Ukraine does not have the elaborated normative regulatory foundation for milk procurement by the Agrarian fund. In addition, the system of state regulation of procurement prices for milk via the introduction of relevant changes to the Law of Ukraine "On Milk and Milk Products" has not been introduced due to some objective and subjective reasons.

At present the problems of season fluctuations lie merely in the plane of actions of managers of agricultural enterprises and heads of private rural farms via introduction of corrections into the technological process.

While evaluating market-related risks, special attention should be paid to the relations of producers and processors of milk. The estimation of the nature of relations between processors and producers of milk - agricultural enterprises - revealed stable economic ties. In 2015-2016 we examined about 200 farms in Kyiv, Khmelnytsky, Ternopil, and Cherkasy regions. It was determined that the relations between processors and $61 \%$ of agricultural enterprises had lasted over 10 years, $26 \%-5-9$ years, $11 \%-2-$ 4 years, $2 \%$ economic subjects - up to 2 years. The survey results demonstrate that in $89 \%$ of farms the level of procurement prices is corrected every 10 days, $11 \%$ - every month. The changes are registered in the corresponding protocols of price coordination. It should be noted that the level of prices is satisfactory only for $37 \%$ of agricultural enterprises, while for $63 \%$ it is unsatisfactory. Thus, milk-processing enterprises consider biological specificities of milk and dictate the level of procurement prices. To determine the quality ingredients of milk, $86 \%$ of surveyed corporate sector farms use the results of laboratory tests of milk-processing enterprises, and only $11 \%$ use both their own results and those of processors. The results of studying the acts on discrepancies demonstrated that the indices of laboratory tests did not differ much, and the deviation was usually detected due to the change in biochemical properties of milk while transporting.

Most milk-processing enterprises make their payments pursuant to the approved schedule, which is an addendum to the agreement on supplying milk. In our opinion, a milk-processing enterprise has a monopoly position in setting the rate of procurement prices and quality parameters of milk regarding agricultural enterprises. To remove the misunderstanding between milk producers and processors about its quality parameters, the Technical Guidelines should include the envisaged 
procedure of identification and evaluation of compliance with quality requirements.

We share the opinion that market-related risks are closely related to technological risks, as milk quality has a decisive impact on the formation of procurement prices. To improve the quality of agricultural products as raw resources for processing enterprises in market conditions, it is relevant to form the approach to its price formation with the consideration of the main technological indices which would condition the increased yield and improvement of the quality of ready products of processing, and is also a valuable economic stimulus for agricultural commodity producers. Still, the deficiency of milk leads to the processors' neglecting the content of fat and protein in milk.

To determine the quantitative dependence of milk price on the volumes of supplies and quality (content of fat and protein), we selected indices of agricultural enterprises for 2015 in different regions. To achieve this purpose, we used a multifactor regression analysis, applied to find a functional dependence between the dependent variable - criterion and independent variable - factors.

We studied the dependence of the price of milk supplies by agricultural enterprises to the processing enterprises $(Y)$ on the following factors: $\mathrm{X}_{1}$ - volumes of milk supplies, thous. t.; $X_{2}-$ mass content of fat, $\%$; $\mathrm{X}_{3}$ - mass content of protein, $\%$.

The reliability of regression coefficients is checked using Student's t-criterion, the table value of which is $\mathrm{T}_{\mathrm{gr}}=2.06$. The actual value of $\mathrm{X}_{2}$ is smaller than that in the Table, thus, the coefficient of regression equation is deemed to be statistically unreliable, and the actor of "mass content of fat" should be removed from the model.

Further study of the dependence of the price $(Y)$ on milk supplies $\left(X_{\nu}\right)$ and mass content of protein $\left(X_{2}\right)$.

The results of evaluations provide for some conclusions. The strength of the relationship between the investigated factors is estimated using the values of multiple correlation coefficient. The correlation-regression analysis demonstrated that the degree of the relationship strength is significant $-\mathrm{R}=0.6515$.

The unit of measuring the simultaneous impact, conditioned by the variation of both factors, included into the study, is a coefficient of multiple determination $\left(\mathrm{R}^{2}\right)$. In our case $\mathrm{R}^{2}$ equals 0.4244 . It means that price variation for $42.44 \%$ depends on the change in the investigated factors.
Thus, determination coefficients, variation in price for milk $(Y)$ for $42.44 \%$ depends on the cumulative impact of both investigated factors, including: by $22.79 \%$ on the volumes of supplies $\left(X_{\nu}\right)$ and by 19.66 $\%$ on the mass content of protein $\left(X_{3}\right)$.

According to Fisher's test, dependence equation is statistically reliable: the estimated value of $F$-criterion 7.37 exceeds the Table value of 3.49 .

The values of t-statistics of both factors exceed the Table value of Student's t-criterion. It confirms the reliability of the impact of selected factors on the result. Thus, we may proceed with economic interpretation of the study results.

The correlation-regression model of the dependence of price on the mentioned factors is as follows:

$$
Y=1164.718+0.000996 X_{1}+932.7123 X_{2}
$$

All the estimated coefficients of the equation are positive. Thus, the price increases with the increase in supplies and content of protein in milk.

The analysis of correlation-regression relationship demonstrated that the increase in supply volumes and higher content of protein by 1 per cent leads to the increase in the effective feature (the price of milk supplies to processing enterprises) by 0.025 and $0.69 \%$ respectively compared to the mean values of the sampling.

According to the provisions of the Association Agreement, Ukraine should approximate the legislation in the sphere of sanitary events to the EU law in maximal possible way. This approximation does not mean copying the requirements of EU legislation. Ukrainian requirements to indices of milk quality and safety in accordance to the Law of Ukraine "On Milk and Milk Products" (No. 1870-IV dated June 24, 2004) do not satisfy consumers completely, as they allow substituting $50 \%$ biologically valuable components of milk resources with other ingredients, which are often of dubious quality [30].

The expiration date of DSTU 3662-97 “Cow's milk, unskimmed. Requirements for procurement" is close. It envisaged the availability of four grades of milk which are considerably different from the European norms (Table 4).

The quality of milk, produced in our country, differs from that in developed countries. It is desirable for the level of bacterial contamination not to exceed 100000 per $\mathrm{ml}$, but in Ukraine the plate count is 300000 per $\mathrm{ml}$ for milk of higher grade, 500000 per $\mathrm{ml}$ - for the first 
grade, and 3 million units $/ \mathrm{ml}$ - for the second grade. Raw milk is subject to mechanic and heat treatment, double pasteurization of raw material, but the usefulness of the product is hereby lost.

Since January 1, 2018, Ukraine has approved DSTU 2662:2015 "Raw cow's milk. Technical conditions", which envisaged the following characteristics: milk for industrial processing - extra, higher and first grade; maximal content of somatic cells $\leq 600$ thousand $/ \mathrm{cm}$, QMAFAnM $\leq 500$ thousand $\mathrm{CFU} / \mathrm{cm}$; milk cooling to $6{ }^{\circ} \mathrm{C}$. The temperature is not set on condition of processing milk within two hours of milking. The period of storing since the moment of milking with the consideration of time for transportation: at the temperature not higher than $4{ }^{\circ} \mathrm{C}-24 \mathrm{~h}$; not higher than $6{ }^{\circ} \mathrm{C}-18 \mathrm{~h}$.

Pursuant to the Association Agreement, Ukraine committed to adjusting its laws to the European legislation, according to which raw milk should comply with the following requirements: absence of inhibitors and residues of veterinary preparations, total bacterial contamination up to 100 thousand and the content of somatic cells not exceeding 400 thousand.

It is noteworthy that enhancing milk quality is mostly the responsibility of the managers of corporate sector farms of agrarian economy. It is obvious that correct organization of technological process decreases industrial risks, in particular, quality parameters of milk and their correspondence to current and new standards. Noteworthy is the fact that in most highly concentrated profitable agricultural enterprises, the technological process is completely adapted to the requirements of DSTU 2662:2015 "Raw cow's milk. Technical conditions". Most mixed enterprises of corporate sector undergo the process of updating the material-technical resources with the anticipated achieving of intended indices up to 2021. In economically unstable farms the level of technological re-equipping corresponds to the indices of the 1990s, and the managers do not intend to invest financial resources into their upgrading.

We share the opinion of scientists that quality management of milk products should be viewed as a directed process of coordinated actions in the system of milk subcomplex of agro-industrial complex to set, ensure and maintain the required level of product quality, which would satisfy the requirements of consumers, enterprises in processing industry and the society in general [31].

It should be noted that different systems of quality management with various methods of enhancing and ensuring the required level of quality of products, works, and services have been available in Ukraine. All the systems envisaged some constructive innovations and advantages, which had a targeted and positive impact on the quality of the products, work and services according to the requirements of a specific period.

The scale of tasks to be solved conditioned the need for unified organization and centralized scientific and methodological management of the elaboration and introduction of comprehensive systems of quality management which would ensure unified policy regarding the quality on all the levels of territorial and field-related management.

However, absolute majority of the presented systems of quality management was notable for some drawbacks: firstly, control procedures were related to the quality of finished products; secondly, only some samples out of the whole batch of finished products were checked; thirdly, the systems of motivation and preparation of personnel required further updating. Therefore, the measures, taken to ensure the required level of quality in the management systems, did not prevent from repeating present drawbacks. Only now there is a

Table 4. The comparison of the requirements DSTU 3662-97 "Cow's milk, unskimmed. Requirements for procurement" and the EC Regulation 853/2004

\begin{tabular}{|c|c|c|c|c|c|c|}
\hline \multirow{2}{*}{ Grade } & \multicolumn{4}{|c|}{ DSTU 3662-97 “Cow's milk, unskimmed" } & \multicolumn{2}{|c|}{ EC Regulation 853/2004 } \\
\hline & extra & higher & first & second & $\mathrm{S}$ - grade & higher \\
\hline Total bacterial contamination, thousand/cc & $\leq 100$ & $\leq 300$ & $\leq 500$ & $\leq 3000$ & $\leq 50$ & $\leq 100$ \\
\hline Temperature, ${ }^{\circ} \mathrm{C}$ & $\leq 6$ & $\leq 8$ & $\leq 10$ & $\leq 10$ & $\leq 4$ & $\leq 6$ \\
\hline Mass content of dry substances, $\%$ & $\geq 12.2$ & $\geq 11.8$ & $\geq 11.5$ & $\geq 10.6$ & $\geq 12.6$ & $\geq 12.2$ \\
\hline Number of somatic cells, thousand/cc & $\leq 400$ & $\leq 400$ & $\leq 600$ & $\leq 800$ & $250-300$ & $\leq 400$ \\
\hline Freezing point & \multicolumn{4}{|c|}{ Not controlled } & \multicolumn{2}{|c|}{$\begin{array}{c}-0.52{ }^{\circ} \mathrm{C} \text { (Directive 92/46/EEC } \\
\text { revis. No. 94/330/EU) }\end{array}$} \\
\hline
\end{tabular}


need to solve problems of safety and ecological properties of milk and milk products, and to implement progressive systems of quality management, which are required by the specifics of market economy mechanism in many countries.

The requirements, related to milk production at holdings, are based on the Regulation (EC) No. 178/2002 of the European Council and Parliament, highlighting general principles and requirements of food legislation and determining the procedures of food product safety (Regulation (EC), 2002) [32]. The programs of HACCP system, which are programs of obligatory preliminary measures on ensuring the safety of food products, are introduced at commercial dairy farms according to ISO/TS 22002-3:2011.

Summarizing the abovementioned, one may make a conclusion that milk production in agricultural enterprises is characterized by increased risks, the manifestation of which is formed by both external and internal media. We believe that it is possible to minimize and neutralize manifestations of the negative impact of risks, coming from the internal medium, by introducing the process approach based on the principles of ISO/TS 22002-3:2011 which would allow building the system of quality management and product safety.

The investigation has revealed that in recent years the introduction of the system of risk management at most domestic enterprises has spread, but has not been fully activated. However, it would be wrong to ascertain that risk management functions had not been fulfilled by them before. The main functions of risk management, which are the same for enterprise management in general are as follows: forecasting, organization, regulation, coordination, stimulation, and control.

Specific functions of risk management, implemented in a somewhat modified form, are as follows: organization of work related to decreasing the magnitude of risk, organization of insurance process, organization of capital investments and economic relations among economic subjects. Thus, there may be an impression of some doubling of functions, already fulfilled by the enterprise. However, a considerable difference in risk management is the fact that the latter is directed at detecting and neutralizing negative phenomena in the activity of enterprise, which hinder the achievement of the targeted aims that cannot be efficiently solved by traditional subsystems of management.

It should be noted that there are two current approaches to organizing the system of risk manage- ment - centralized and decentralized ones. The centralized approach is based on the fact that risk management is performed by specific divisions using the data, provided by other divisions and services, which allows for more efficient response to the occurrence of risk situations. The essence of the centralized approach lies in the fact that the evaluation and management of risks is performed independently by each division, the division of risk management only creates the methods of management and deals with the monitoring of management process.

In our opinion, a mixed two-level system of risk management will be most efficient, i.e. risk factors, remarkable for the enterprise, are detected on a higher level, and the ones, notable for dairy farming, for instance, are revealed at the lower one. This approach allows fulfilling the planning function to the fullest degree, when scheduled indices are determined both for the whole enterprise and for each division.

It is reasonable to elaborate a specific set of functions for each level. The first level should have functions of coordinating activity, elaborating methodological approaches to evaluating the risks, the efficiency of risk management system in general, etc. The main functions for the lower level are determining risk factors and achieving the aims, set for dairy farming division, which would ensure economic stability of milk production.

The functionality of risk management system in dairy farming mostly depends on the rational structure and operational capability of the lower level of management. The analysis and evaluation of risks are not exhaustive measures of ensuring the stability of agricultural milk-producing enterprises as it is relevant to elaborate a system of measures, directed at the adaptation of agricultural enterprises to the impact of risk factors.

The main strategy of any enterprise, including an agricultural one, is achieving the highest efficiency and profitability, and thus stability. The tactics envisages the system of methods and techniques, used to achieve the set aims within a short-term period. We believe that all the measures on neutralization and minimization of the negative impact of risks may be considered by the following approaches: avoiding risk; transferring risk; assuming risk for oneself, within which the following approaches may be distinguished - decreasing or minimizing the level of risk, compensation of probable negative consequences, localization. 
We believe that preventive measures are reasonable, if there are actual possibilities of decreasing the probability of risk or the sum of probable losses, or removing this kind of risk completely. The measures, taken pursuant to this method, are as follows: elaborating the system of internal norms (limitation), evaluating the degree of risk of taking decisions, applying the methods of compensations.

Containing risk (assuming risk for oneself) is reasonable in the following cases: if the expenses for insurance are too high; after preventive measures have been taken and they have been insufficient to impact the market situation; the losses from the insured event are insignificant; there are no other opportunities of protecting from the risk.

According to this method, the enterprise assumes the responsibility for the risk and reimburses all the losses. Specific measures are diversification of industrial activity, obtaining additional information, etc.

Avoiding risk envisages decreasing probable losses from the risk event. According to this approach, the measures may be as follows: refusing from practical implementation of a specific management decision, which conditions the manifestation of risk, checking the information about contractors and consumers, which is aimed at detecting unreliable ones and breaking the relations with them, and refusing from risky kinds of activity.

However, while applying this method, one should take into consideration that the enterprise loses probable income, related to this kind of activity. In addition, avoiding one kind of risk may result in the occurrence of others, and in case of taking a risky decision the enterprise may receive profit, which would exceed probable losses.

Self-insurance lies in creating the system of material and financial reserves at the enterprise. This method is recommended in the following situations: the probability of losses is insignificant; it is possible to forecast losses, but it is impossible to prevent them (for instance, natural disasters, epidemics). Insurance allows reducing the dependence and cutting losses when the risk event occurs. The method is used if it is possible to determine the probability of the insured event and estimating the magnitude of the possible damage. Modern approaches to risk management should also include transfer of risk in a different way, compared to insurance, i.e. transferring the responsibility for risk to the third parties. Management techniques are receiving financial guarantees, hedging, concluding long-term agreements with milk-processing enterprises, etc.

Taking into consideration the need to increase control over the quality of milk production, the suggested Technical Regulation should include the requirements to the organization of industrial control, which would envisage the following: the producer should organize the industrial control in accordance with HACCP, GMP or other systems of ensuring safety and quality of raw milk; documents of industrial control should be approved by the head of the organization, private entrepreneur or an authorized person in the proper way; legal entities or private producers of milk should provide information about the results of industrial control on request of the authorized body of executive power within the scope of competence of the latter; in force majeure situations, disruption of production processes, which create threat to life or health of citizens and animals, property, environment, producers should inform a specially authorized body of executive power, which exercises functions of state monitoring and control, as well as their local bodies, within the scope of competence of the latter, specified by the law.

\section{CONCLUSIONS}

The study results prove that the change in climatic conditions triggers the occurrence of risks, related to the decrease in the productivity of cows in the periods of higher temperatures, the decrease in milk quality, where functional instruments of management are decreasing the negative impact of heat stress by creating comfortable conditions of keeping animals, and having the diet, balanced in terms of energy. As for the willingness of domestic commodity producers to implement the instruments of adapting to climate changes and decreasing the negative impact of industrial activity on environment, it should be noted that there is a low level of investments into nature protecting measures, waste disposal, and there are outdated systems of keeping manure. In its turn, it requires a complex of awareness events on the regional levels of management for managers of dairy farming holdings about the negative impact of these processes on environment, reputation and economic losses, and scientific support in implementing nature protective events by prominent scientists of agrarian educational and scientific institutions.

It was determined that the violation of technological requirements of milk production and keeping cows, absence of the relevant system of biosafety condition the occurrence of technological risks, including higher loss 
of cattle, reduced period of productive use of cows, violations of scientifically grounded norms of herd cycle, etc., and higher production costs, which are aggravated due to the absence of scientifically grounded norms of cattle loss. We believe that managers of agricultural enterprises should have systematic control over technological and reproduction indices, elaborate and approve the norms of admissible technological loss and damage based on species composition, technology and other parameters, and introduction of automated systems of managing a dairy herd.

We believe that minimization and neutralization of technological risks in dairy farming will be promoted by enhancing biosafety of animal breeding complexes and developing the insurance of agricultural animals. In this respect, it is critical that obligatory insurance of dairy herds does not cover all the agricultural producers in the country, not mentioning the general population. Therefore, it is relevant to have the events of preventing the risk of dermatitis nodularis epidemic in the territory of our country, which requires elaborating the program of both vaccination and obligatory identification and registration of animals on the national level.

It was established that it is possible to minimize price risks in dairy farming on condition of the equal share of prices, which is confirmed by the following facts: the increase in the productivity of cows by $1 \mathrm{~kg}$ increases milk profitability by $0.005 \%$ regarding the average values; the increase in equal share indices to cumulative expenses, to material-technical expenses and costs of fodder by $1 \%$, the quality milk profitability by 0.3 ; 0.29 and $0.21 \%$ respectively. In addition, the fluctuation of prices for milk is under the impact of season factor, the elimination of which depends on managers of the enterprise, who should elaborate scientifically grounded plans of herd cycle and the industrial program, and conclude long-term agreements for milk supply with processing enterprises. This conclusion is confirmed by the fact that the variation in the price for milk by $42.44 \%$ depends on the cumulative impact of the volumes of supplies and the mass content of protein by $22.79 \%$ and $19.66 \%$ respectively.

Summarizing the study results regarding the identification of risks of agricultural milk-producing enterprises, one may come to a conclusion that their systematization should be conducted both according to the general system of their manifestation, and to the specialized identification which characterizes specificities of the industry. It was proven that the probability of manifestation of most risks, occurring in dairy pro- duction, is considerably dependent on the efficiency of management of the agricultural enterprises and partially on legislative and executive branches of power (in the part of legislative provisions). In current conditions, the elimination of risks of the environment is possible only if there is search for internal reserves (extension and improvement of the species composition of the herd, scientifically grounded system of feeding, proper attention to nature protecting activity, compliance with zoohygienic and veterinary norms of keeping animals, control over loss of herd), ensuring the stability of dairy farming which envisages creating conditions for the production of high quality milk, minimization of expenses for its production and sale, compliance with agreement conditions with contactors.

This article does not relate to any studies using humans and animals as investigation subjects.

Conflict of interests. The authors deny any conflict of interests.

Financing. This study did not receive any specific grant from the financing institutions in state, commercial or non-commercial sectors.

\section{Ризики молочного скотарства України та напрями їх мінімізації і нейтралізації}

О. М. Варченко ${ }^{1}$, В. І. Радько ${ }^{2}$, О. О. Рудич ${ }^{1}$, I. В. Свиноус ${ }^{1}$, К. В. Ткаченко ${ }^{1}$

${ }^{1}$ Білоцерківський національний аграрний університет 8/1, Соборна площа, Біла Церква, 09117, Україна

${ }^{2}$ Національний університет біоресурсів і природокористування

11, Вул. Героїв оборони, Київ, 03041, Україна

e-mail: omvarchenko@ukr.net,radko@ukr.net, 8282@ukr.net, isvinous@ukr.net, k-tkachenko@ukr.net.

Мета. Ідентифікувати основні видів ризиків, що притаманні сільськогосподарським підприємствам з виробництва молока та здійснити оцінку наслідків їх настання, а також обгрунтувати комплексну систему управління ними на рівні підприємства, що сприятиме їх мінімізації та нейтралізації. Методи. У процесі дослідження застосовували загальноприйняті методи і прийоми: сукупність наукових прийомів абстрактно-логічного методу у розробці теоретичних положень, метод дедукції при виділенні специфічних ризиків у молочному скотарстві із загальної сукупності, емпіричні методи при дослідженні діяльності підприємств молочного напрямку та імітаційне комп'ютерне моделювання при обгрунтуванні практичного інструментарію ризик-менеджменту у сільськогосподарських підприємствах 3 виробництва молока. Статистичну обробку даних і pe- 
зультатів досліджень проводили із застосуванням кореляційно-регресійного аналізу. Результати. У процесі дослідження було виділено наступні види ризиків у молочному скотарстві: природні, екологічні, технологічні, ринкові. Природний ризик, пов'язаний із впливом навколишнього середовища, в першу чергу, із зміною температурного режиму середовища утримання корів, екологічна складова утилізації гною. Технологічний ризик характеризується порушенням умов утримання корів у сільськогосподарських підприємствах, прояв якого характеризується падежем і вибраковуванням корів 3 основного стада. Встановлено, що у нинішніх умовах для сільськогосподарських підприємств підвищеним ризиком $є$ поширення хвороб, тобто епізоотична ситуація в країні. Одним із заходів нейтралізації та мінімізації прояву технологічних ризиків $\epsilon$ підвищення біобезпеки тваринницьких комплексів та розвиток страхування сільськогосподарських тварин. Окрім ризиків хвороб (інфекційні, інвазійні, незаразні) та інших стандартних ризиків (пожежа, стихійні лиха i т.д.) доцільно приймати на страхове покриття такі види ризиків: перерва у виробництві (викликана смертю або втратою застрахованих тварин), при настанні якої автоматично або при наданні підтверджувальних документів, відшкодовуються поточні витрати на продовження господарської діяльності або упущений прибуток; транспортування тварин, включаючи морські, авіаційні, залізничні перевезення; витрати з видалення залишків тварин після настання страхової події, що спричинило їх смерть; компенсація витрат на ліквідацію наслідків, викликаних інфекційними хворобами, в результаті яких неможливо відновити виробництво без попереднього застосування дезінфікувальних засобів. Особливу увагу при оцінюванні ринкових ризиків слід приділити взаємовідносинам виробників і переробників молока. Ринкові ризики тісно переплітаються з технологічними ризиками, оскільки якість молока має визначальний вплив на формування закупівельних цін. Висновки. Систематизація ризиків молочного скотарства повинна проводитись відповідно до загальної системи їх прояву, а також відповідно до спеціалізованої ідентифікації, яка характеризує специфічні особливості галузі. Ймовірність прояву більшості ризиків, які виникають у процесі виробництва молока, визначально залежить від ефективної діяльності менеджменту сільськогосподарських підприємств і частково від законодавчої та виконавчої влади (у частині законодавчого забезпечення). У нинішніх умовах нівелювання прояву ризиків зовнішнього середовища можливе лише за умови пошуку внутрішніх резервів забезпечення стійкості молочного скотарства, що передбачає створення умов для виробництва високоякісного молока, мінімізацію витрат на його виробництво та реалізацію, дотримання договірних умов з контрагентами.
Ключові слова: молочне скотарство, галузевий ризик, природний ризик, технологічний ризик, екологічний ризик, ринковий ризик.

\section{Риски молочного животноводства Украины} и направления их минимизации и нейтрализации

\author{
О. М. Варченко ${ }^{1}$, В. И. Радько ${ }^{2}$, А. А. Рудич ${ }^{1}$, \\ И. В. Свиноус ${ }^{1}$, К. В. Ткаченко ${ }^{1}$
}

${ }^{1}$ Белоцерковский национальный аграрный университет 8/1, Соборная площадь, Белая Церковь, 09117, Украина

${ }^{2}$ Национальний университет биоресурсов и природопользования

11, Ул. Героев обороны, Киев, 03041, Украина

e-mail: omvarchenko@ukr.net, radko@ukr.net,8282@ukr. net, isvinous@ukr.net,k-tkachenko@ukr.net.

Цель. Идентифицировать основные виды рисков, присущих сельскохозяйственным предприятиям по производству молока и осуществить оценку последствий их наступления, а также обосновать комплексную систему управления ими на уровне предприятия, что будет способствовать их минимизации и нейтрализации. Методы. В процессе исследования применялись общепринятые методы и приемы: совокупность научных приемов абстрактно-логического метода в разработке теоретических положений, метод дедукции при выделении специфических рисков в молочном скотоводстве в общей совокупности, эмпирические методы при исследовании деятельности предприятий молочного направления и имитационное компьютерное моделирование при обосновании практического инструментария риск-менеджмента в сельскохозяйственных предприятиях по производству молока. Статистическую обработку данных и результатов исследований проводили с применением корреляционно-регрессионного анализа. Результаты. В процессе исследования были выделены следующие виды рисков в молочном животноводстве: природные, экологические, технологические, рыночные. Природный риск, связанный с влиянием окружающей среды, в первую очередь, с изменением температурного режима среды содержания коров, с экологической составляющей утилизации навоза. Технологический риск характеризуется нарушением условий содержания коров в сельскохозяйственных предприятиях, проявление которого характеризуется падежом и выбраковкой коров из основного стада. Установлено, что в нынешних условиях для сельскохозяйственных предприятий повышенным риском является распространение болезней, то есть эпизоотическая ситуация в стране. Одной из мер нейтрализации и минимизации проявления технологических рисков является повышение биобезопасности животноводческих комплексов и развитие страхования сельскохозяйственных животных. Кроме рисков болезней (инфекционные, 
инвазионные, незаразные) и других стандартных рисков (пожар, стихийные бедствия и т.д.) целесообразно принимать на страховое покрытие следующие виды рисков: перерыв в производстве (вызванный смертью или потерей застрахованных животных), при наступлении которой автоматически или при предоставлении подтверждающих документов возмещаются текущие расходы на продолжение хозяйственной деятельности или упущенная прибыль; транспортировки животных, включая морские, авиационные, железнодорожные перевозки; расходы по удалению остатков животных после наступления страхового события, повлекшее их смерть; компенсация расходов на ликвидацию последствий, вызванных инфекционными болезнями, в результате которых невозможно восстановить производство без предварительного применения дезинфицирующих средств. Особое внимание при оценке рыночных рисков следует уделить взаимоотношениям производителей и переработчиков молока. Рыночные риски тесно переплетаются с технологическими рисками, поскольку качество молока имеет определяющее влияние на формирование закупочных цен. Выводы. Систематизация рисков молочного животноводства должна проводиться в соответствии с общей системой их проявления, a также в соответствии $\mathrm{c}$ специализированной идентификации, которая характеризует специфические особенности отрасли. Вероятность проявления большинства рисков, возникающих в процессе производства молока, изначально зависит от эффективной деятельности менеджмента сельскохозяйственных предприятий и частично от законодательной и исполнительной власти (в части законодательного обеспечения). В нынешних условиях нивелирование проявления рисков внешней среды возможно лишь при условии поиска внутренних резервов обеспечения устойчивости молочного животноводства, которая предусматривает создание условий для производства высококачественного молока, минимизацию затрат на его производство и реализацию, соблюдение договорных условий с контрагентами.

Ключевые слова: молочное животноводство, отраслевой риск, природный риск, технологический риск, экологический риск, рыночный риск.

\section{REFERENCES}

1. Samsonenko DO. The dairy cattle breeding may be profitable. Naukovyi visnyk "Askania-Nova". 2018; (11):131-5.

2. Martunyuk GP. Prospects for development of stock breeding in the agrarian formations of Zhytomyr region. Biznes inform. 2015;(7):178-85.

3. Ivanova LS. Milk succession: current status and problems of solution. AgroSvit, 2017;(22):23-7.

4. Troels Kristensen, Ole Aaes, Martin Riis Weisbjerg.
Production and environmental impact of dairy cattle production in Denmark 1900-2010. Livestock Sci., 2015;178:306-12. doi: 10.1016/j.livsci.2015.06.012.

5. Seyedsharifi $R$, Ghadimi M, Evrigh $N H$, Seifdavati J, Boustan A, Benamar HA. Economic evaluation in traditional and industrial livestock with different levels of milk production in Ardebil province with emphasis on risk criteria. Kafkas Univ. Vet. Fak. Derg. J., 2018;24(5):681-9. doi: 10.9775/kvfd.2018.19720.

6. Varchenko OM, Krysanov DF, Shust OA. Innovations of agro-food chains in Ukraine. Agric. Sci. Pract., 2017;4(3):73-83. doi: 10.15407/agrisp4.03.073.

7. DiakitéZR, CorsonMS, BrunschwigG,BaumontR, Mosnier $C$. Profit stability of mixed dairy and beef production systems of the mountain area of southern Auvergne (France) in the face of price variations: Bioeconomic simulation. Agric. Systems., 2019;171(C):126-34. doi: org/10.1016/j.agsy.2019.01.012.

8. Zubchenko $V V$. Specificities of organizing the reproduction of dairy herd in agricultural enterprises. Ekonomika ta upravlinnia APK, 2014;(2):57-62. [In Ukrainian].

9. Denis-Robichaud J, Cerri RLA, Jones-Bitton A, LeBlanc $S J$. Dairy producers' attitudes toward reproductive management and performance on Canadian dairy farms. J. Dairy Sci., 2018;101(1):850-60. doi: 10.3168/jds.201612416.

10. Ross SA, Topp CFE, Ennos RA, Chagunda MGG. Relative emissions intensity of dairy production systems: Employing different functional units in life-cycle assessment. Animal, 2017;11:1381-8. doi: 10.1017/ S1751731117000052.

11. Brandt P, Herold M, Rufino MC. The contribution of sectoral climate change mitigation options to national targets: A quantitative assessment of dairy production in Kenya. Environ. Res. Lett., 2018;13(3). doi: 10.1088/ 1748-9326/aaac84.

12. Hajer Amamou Mohsen, Ben Sassi, Hatem Aouadi, Hichem Khemiri, Mokhtar Mahouachi, Yves Beckers, Hedi Hammami Climate change-related risks and adaptation strategies as perceived in dairy cattle farming systems in Tunisia. Climate Risk Management. 2018; 20:38-49. doi.org/10.1016/j.crm.2018.03.004.

13. Rudych $O O$. The economic essence of risk and particular manifestations in the activities of agricultural enterprises. Ekonomika ta upravlinnja APK. 2012;93(7):59-63.

14. Ruda TP. Formation of the system of management of economic risks of dairy processing enterprises. Ekonomika ta upravlinnja APK. 2012;95(8):118-22.

15. Korzh $N V$. Financial risk management methods. Inter. Electronic J. Sci., 2016;2(10), pp. 1.1-1.6. doi: http:// dx.doi.org/10.22178/pos.15-3.

16. Bondarevska $K$. State regulation as a factor of sustainable economic development. MEST J. 2014;2(2):23-31. doi: 10.12709/issn. 2334-7058 
17. Druchek K, Shvedun $V$. The assessment of risks of foreign economic activity of the industrial enterprise in public administration. Visnik Natsionalnogo universytetu tsyvilnogo zahystu Ukrainy. 2017;2:106-15. doi: 10. 5281/zenodo.1038908.

18. Terje Aven. Risk assessment and risk management: Review of recent advances on their foundation. Eur. J. Operat. Res. 2016;253(1):1-13. https://doi.org/10.1016/j. ejor.2015.12.023.

19. Edward Qian. Risk Parity and Diversification. J. Investing. 2011;20(1):119-27. doi: https://doi.org/10.3905/ joi.2011.20.1.119.

20. Ted O'Donoghue, Jason Somerville. Modeling Risk Aversion in Economics. J. Econom. Perspect. 2018; 32(2):91-114. doi: 10.1257/jep.32.2.91.

21. Chinchilla-Vargas J, Jahnke MM, Dohlman TM, Rothschild MF, Gunn PJ. Climatic factors affecting quantity and quality grade of in vivo derived embryos of cattle. Anim. Reprod. Sci., 2018;192:53-60. doi: 10.1016/j. anireprosci.2018.02.012.

22. Chernenko OM, Chernenko OI, Shulzhenko NM, Bordunova OG. Biological features of cows with different levels of stress resistance. Ukr. J. Ecol., 2018; 8(1):466-74. doi: 10.15421/2017_237.

23. Trajchev $M$, Nakov $D$, Andonov $S$. The effect of thermal environment on daily milk yield of dairy cows. Maced. Vet. Rev., 2016;39(1):185-92. doi: 10.1515/ macvetrev-2016-0084.

24. Borshch OO, Borshch OV, Donchenko T, Kosior L, Pirova $L$. Influence of low temperatures on behavior, productivity and bioenergy parameters of dairy cows kept in cubicle stalls and deep litter system. Ukr. J. Ecol., 2017;7(3):73-7. doi: http://dx.doi.org/10.15421/ 201751.

25. Miniailo $O$, Miniailo $V$, Linetska $Y$. Milk-product subcomplex of Ukraine: trends of development. Tovary i rynky. 2018;(4):20-35. doi: https://doi.org/10.31617/ tr.knute.2018 (28) 02.
26. Rudenko EV, Trishin AK, Pomitun IA, Podobed LI, Shkavro NN. Urgent issues of cattle production technologies and quality ensuring development in Ukraine. Naukovo-tehnichnyi biuleten IT NAAN, 2018;(120):313. doi: 10.32900/2312-8402-2018-120-3-13.

27. Saegerman C, Bertagnoli S, Meyer G, Ganière J-P, Caufour $P$, De Clercq $K$, Jacquiet P, Fournié $G$, Hautefeuille C, Etore F, Casal J. Risk of introduction of lumpy skin disease in France by the import of vectors in animal trucks. PLoS One, 2018;13(6):e0198506. doi: 10.1371/journal.pone.0198506.

28. Tretiak $K$. Agricultural insurance: foreign experience and resources for its implementation in the Ukrainian insurance practice. Efektyvna ekonomika, 2019;(1). doi: 10.32702/2307-2105-2019.1.32.

29. Malik M, Hudz H. Organization of insurance defence in agrarian enterprise - foreign experience. Bull. T. Shevchenko National University of Kyiv, 2015;8 (173):19-25. doi: dx.doi.org/10.17721/1728-2667.2015/ 173-8/3.

30. Dzhedzhula VV, Jepifanova IYu, Hladka DO. Dairy market: condition and development trends. Ekonomika i suspilstvo. 2018;(18);382-8. doi: https://doi.org/10.32782/ 2524-0072/2018-18-53.

31. Prilipko T, Bukalova N. Evaluation of quality and safety of milk on admission to milk-processing company from different entities. Naukovyi visnyk LNUVMBT imeni S.Z. Gzhitskogo. 2016;18(2):212-5. doi: 10.15421/ nvlvet6747.

32. Bogatko N, Lyasota V, Bukalova N, Artemenko L, Bogatko L, Salata V, Dashkovskyy O. Sanitary and hygienic assessment of milk of different producers in conformity with international requirements. Scientific Messenger of Lviv National University of Veterinary Medicine and Biotechnologies. Series: Veterinary Sciences publishes peer-reviewed original research articles and reviews on different aspects of veterinary medicine, 2018;20(83): 88-92. doi: 10.15421/nvlvet8317. 